\title{
Whither Intellectual Diversity in American Political Science? The Case of APSA and Organized Sections
}

\author{
Joseph Losco, Ball State University
}

To o speak of political science as a "discipline" may be inappropriate. Both in origin and continuing development, the study of politics is perhaps more an amalgam of different approaches and perspectives, sometimes in competition for temporary dominance, than a discipline in any unified sense. It has been subject to the ebb and flow of ideas from a variety of disciplines and fashions. Vernon Van Dyke (1960) documented political science's experimentation with methods pioneered in other disciplines including sociology, geography, psychology, and economics. He noted that, since its founding, the discipline had been characterized by changing fashions in the units of analysis chosen for examination, including variables related to institutions, personal characteristics, law, values, power, group behavior, and decision making. This "looseness" in our field of study is probably not unique to political science and may serve practitioners well, since it inhibits fossilization by preventing too strong a reliance upon any particular method or approach. But it has certainly not produced a unified field of study. As David Easton remarked, "If there is one thing that distinguishes Western political science, it is that it has not yet arrived at a consensus on how to describe its subject matter at the most inclusive level" (1993, 291). Perhaps, more to the point, when assessing their study of political sci-

Joseph Losco is professor of political science at Ball State University, where he teaches political theory and American government. His publications include Political Theory: Classic Readings, Contemporary Views /coedited with Leonard Williams, St. Martin's Press, 1992), Human Nature and Politics (coedited with Albert Somit, JAI Press, 1995), and Higher Education in Transition (coedited with Brian Fife, Greenwood Press, forthcoming). ence as a discipline, Farr and Seidelman noted, "Indeed, it is these long-standing debates, not some fundamental agreement on longstanding principles, that give the discipline the identity it now has" (1993, 7).

The American Political Science Association has served as a focal point for battles over the proper study of politics and provided the stage upon which debate and growth have taken place. In 1982, the Association encouraged greater intellectual diversity by ceding power in planning and organizing subfields to various groups, or Organized Sections, and in 1994 limited the growth in sections to provide greater coherence and central control within the Association. These events do not stand out as unique; rather, they reflect the ebb and flow that have characterized the history of the Association (and of the field of study) since its inception. An investigation of these events and their place within the history of the field may yield insights into future directions.

\section{Theoretical Considerations}

Robert Merton's (1938) work set the stage for the study of scientific investigation years ago. Since then, it has been commonplace to speak of science as a social enterprise, the development of which depends in large part upon factors external to the scientific method itself. Associations, professional contacts, reference groups, and the like all play a part in channeling scientific enterprise in certain directions. Organizational structure is one of the external components that can impact scientific development. The manner in which an organization supports certain routes over others can have profound effects on the direction scientists take. "Men of knowledge," Merton wrote,

do not orient themselves exclusively toward their data, nor toward the total society, but to special segments of that society with their special demands, criteria of validity, of significant knowledge, of pertinent problems, and so on. It is through anticipation of these demands and expectations of particular audiences, which can effectively be located in the social structure, that men of knowledge organize their own work, define their data, seize upon problems. Hence, the more differentiated the society, the greater the range of such effective audiences, the greater the variation in the foci of scientific attention, of conceptual formulations, and of procedures for certifying claims to knowledge. $(1973,34)$

It is with this perspective in mind that I take a look at the role APSA and its Organized Sections, which reflect the research interests of its members, have played in shaping the recent growth in the study of politics.

Organizations do not exist in a political vacuum. As Lowi has noted, "Political science is itself a political phenomenon, the product of the American state." More particularly, Lowi argued, "even assuming we are all sincerely searching for the truth (and it is more interesting to assume that), there are reasons other than the search for truth why we do the kinds of political science we do, and there are reasons other than the search for truth why particular subdisciplines become hegemonic" (1993, 383). Scientific investigation is influenced as much by the external political environment, the structure of the professional organizations to which investigators belong, and the needs of these investigators 
as it is by the nature of the subject investigated.

Organizations tend toward stability (Berger and Luckman 1966). Potential disruption of stability can come from new people, new ideas, or structural changes. But, as Berger and Luckman noted, disputes over the proper construction of reality rarely are settled on the basis of facts aione. "Extra theoretical interests" including the structure of support for competing subgroups are often decisive" (110-11).

Over the life of an organization, it is likely that there will be periods of growth and contraction. Often, the causes of growth are diverse. Growth can result from external causes-including chance discoveries, prominent findings, or an increase in the number of practitioners-or it can be engineered centrally-as when organizations make new resources or authority available to individuals formerly excluded or increase incentives to attract newcomers. Contraction, likewise can be effected by external or internal factors. Carley (1991) proposed a model demonstrating natural oscillations in groups based on the introduction of new ideas and new people. Diversity brings with it the potential for new insights but challenges group stability. Stability insures cohesiveness but impedes productivity. Over time, large groups move toward reconstruction and stability. In the absence of barriers to new entrants and ideas, however, the period of stability will not last.

Over the course of the last 15 years, APSA has experienced impressive growth (Rudder 1998). One of the factors seemingly spurring that growth has been the development of research communities, spe- cifically the Organized Sections. The sections have been developed largely from the bottom-up and have encouraged greater diversity of interests within the Association. Through these sections, new people and new ideas have entered into a field that is already noted for diversity in method and approach. I will examine some of the concerns that arose within the Association regarding growth of the Organized Sections, review the response taken by the Association, and indicate some of the changes beginning to occur as a result of the Association's response. Finally, I will speculate about future organizational directions in the study of politics.

\section{Looking Back ....}

The discipline has gone through fairly identifiable periods of intellectual growth and change (Somit and Tanenhaus 1967, 4). Some of these developments predate the founding of APSA, going back to a period when those interested in the study of politics met at the American Historical Association or the American Economics Association. Yet, from its inception in 1903 at Tulane University under its first president, Frank J. Goodnow, the American Political Science Association has been the main stage upon which change in the discipline has played out.

Easton $(1993,292)$ dated the first period of the modern study of politics from the latter quarter of the nineteenth century to around the 1920s. The focus of discussion during this era was the state, and the period was dominated by the use of comparative and historic methodologies. Referring to this period as the "formal" stage, Easton described it as one guided by the assumption of a close fit between the dictates of law and actual practice. Discontinuities between law and practice led to con- ceptual reformulations associated with the ideas of Walter Bagehot and Woodrow Wilson in the second era, which Easton called the "traditional" period.

Farr and Seidelman (1993) closed out the first stage much earlier than Easton, pegging the beginning of the second era to the establishment of the American Political Science Association in 1903. APSA brought greater institutionalization and differentiation to the study of politics. The focus of study moved away from the state, Farr and Seidelman claimed, to the dual attempt to discern "real" (as opposed to formal) political processes and the attempt to give scientific support to the reform movement. Charles Beard was cited as one of the most prominent representatives of this second era. During this era, theories from sociology and psychology were imported into political science, giving rise to what Farr and Seidelman called the "first" behavioral revolution.

World War II made political scientists think twice about possibilities for reform, and they distanced themselves from reform movements. The third stage, ushered in by the end of the war, was marked by a vast expansion of the research university and the professionalization of the discipline. College and university faculty became the largest contingent within APSA. Political scientists sought to get their share of increased fiscal support flowing from government and private foundations. In a period of fascination with developments in technology and the "hard" sciences, it became clear that the bulk of the resources would go to those who developed more "objective" and methodologically sophisticated approaches to the study of politics. Predictably, the period culminated with the "second" behavioral revolution. Easton (1993, 294-95) explained this revolution as predicated on the assumption of uniformities in behavior discoverable by empirical procedures, greater rigor in methods, greater theoretical sophistication, sharper separation of fact and value, and a focus on basic, as opposed to applied, research. This second behavioral period coincided with the decades of the most 
rapid growth of the American Political Science Association. From 1946 to 1966, APSA membership increased from 4,000 to 14,000 (Farr and Seidelman 1993, 201).

External events again influenced future directions as the discipline entered its fourth era in the 1960 s and 1970s. Vietnam, social unrest, and the civil rights movement all challenged the hegemony of behavioralism within the discipline and within the Association. To many, behavioralism appeared unrelated to world events. Pluralism didn't seem to explain adequately the reaction of power centers to the demands of diverse new groups seeking entry. Meanwhile, students of the sociology and history of science raised fundamental questions about the scientific enterprise itself, challenging its assumptions of and claims to objective truth (see, for example, Kuhn 1962). These events ushered in the postmodern era that continues today, one characterized by a plurality of methods and approaches. As Farr and Seidelman noted, "postbehavioralism has turned out to provide an intellectual ambience for a great deal of scholarly production that most agree is not governed by some overall purpose or mission. Scholars go their own ways, do their own things, or sit at their own separate tables" (1993, 286).

While there is a great deal of agreement about the stages of disciplinary development, there is far less agreement about how to characterize the current era. Easton wrote that political science had "lost its purpose" upon entering the $1990 \mathrm{~s}$ $(1993,300)$. He lamented the fact that no single, dominant point of view informed all work within the discipline. Yet, he was hopeful that applied research emerging from private institutes and think tanks would facilitate greater methodological rigor, especially by encouraging incorporation of econometric models. Reflecting the aspirations of the earlier behavioral era, he argued that policy institutes "reawakened the hope of an earlier day for integrating the social sciences, at least in the application of knowledge" (301).
Siedelman described the recently engaged postbehavioral dialogue within the profession as potentially capable of returning the discipline to the reform heritage of its prebehavioral days but currently too self-

absorbed to move beyond internal debate. There was a reform tradition that was part of early political science. Citing the works of Lester Ward, Woodrow Wilson, Charles Beard, Arthur Bentley, and, to a

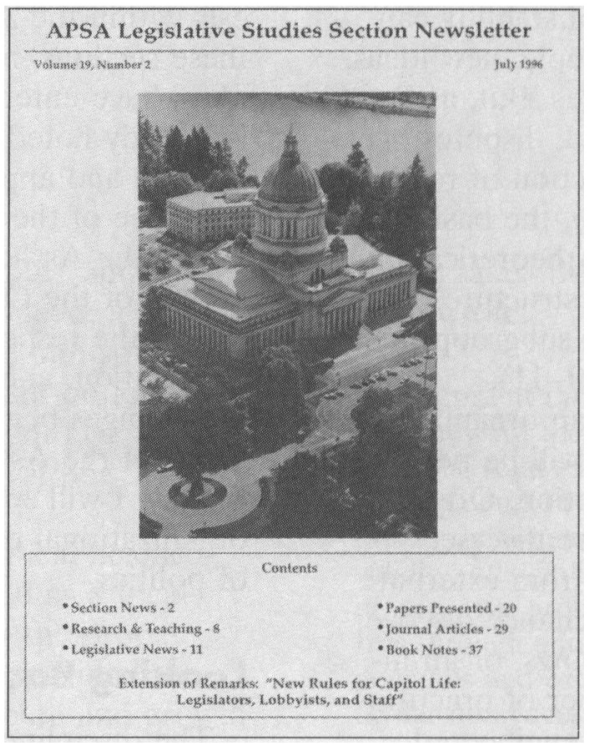
lesser extent, Charles Merriam and Harrold Laswell, Seidelman argued that all believed their job was to bring knowledge to bear on solving or explicating problems in the modern liberal state (1993, 313). For a variety of reasons, the connections between political science and informed publics of the

liberal state broke down about the time of WWII. They were not taken up again afterward. Instead, the discipline turned inward and questions of method and science became dominant. This coincided with the professionalization of political science. Only at the dawn of the postbehavioral stage did the discipline try to move closer to dialogue with the polity. Despite overt moves to address social problems through the formation of the Caucus for a New Political Science in the late 1960s, postbehavioralism's legacy for the Association has been greater attention to internal constituencies-reforming the Association, and planning and assisting the restructuring of collegiate departments and universities. "The 'reform public' became other colleagues in the profession, and critiques became an effort to educate and mobilize other professionals" (Seidelman 1993 , 319). Discipline reformers, Seidelman lamented, "dedicated themselves to self-reflection about theories and methods within their own ranks and came to equate improvement of the profession with more professionalization" (320).

Ross portrayed the discipline as stuck in a cyclical pattern alternating between activism and social reform, on the one hand, and the search for a value-free science, on the other. Periodically, he wrote, "waves of scientists recede under the impact of political activism and the failure of scientific results to match scientific rhetoric, and ... conservative political pressures and the recognition of scientific inadequacy send social scientists again into a renewed commitment to the development of an objective science" $(1993,104)$. These recurrent cycles appear to be rooted 
Table 1

APSA Members, 1974-82

\begin{tabular}{cccr}
\hline Year & Regular & Student & \multicolumn{1}{c}{ All $^{\star}$} \\
\hline 1974 & 7,793 & 4,006 & 12,254 \\
1975 & 7,335 & 3,912 & 11,702 \\
1976 & 7,428 & 3,603 & 11,506 \\
1977 & 7,228 & 3,076 & 10,811 \\
1978 & 7,094 & 2,655 & 10,301 \\
1979 & 6,845 & 2,335 & 9,729 \\
1980 & 6,592 & 2,159 & 9,321 \\
1981 & 6,423 & 1,901 & 8,894 \\
1982 & 5,838 & 1,984 & 8,441 \\
\hline
\end{tabular}

Source: Rudder $(1990,478)$.

* Includes Retired, Life, and Family members. Regular and Student Memberships combined do not yield total memberships. Associate Memberships were not recorded until 1985.

in the political and institutional contexts and bifurcated aims of the social sciences-contexts and purposes that were firmly established during the formative decades of the social sciences in America.

\section{APSA's Postbehavioral Strategies}

For a number of reasons that are not well documented, APSA suffered a serious loss in support at the dawn of the postbehavioral age. ${ }^{1}$ Individual memberships began declining precipitously in the $1970 \mathrm{~s}$. From 1974 to 1982 , individual membership declined nearly a third, from 12,254 members to 8,441 . The drop occurred among all categories of members except retirees, whose numbers continued to grow. Regular membership fell by 1,955 and student membership declined by 2,022 during this period (see Table 1).

Under new leadership, APSA's governing body, the APSA Council, undertook a series of institutional changes beginning in 1981 that stemmed membership decline. These steps included offering journal discounts; adding articles on contemporary politics in $P S$, the journal of record for the Association; offering different hotel rates for members and nonmembers at the Association's Annual Meeting; and mounting other promotional activities. Most notable from a structural perspective was a change the Council made in the operation of the Association itself. To this time, the Association was organized around a limited number of traditionally-defined subfields. Elected representatives from these subfields made up the bulk of the Program Committee responsible for the creation of panels for the Official Program at the yearly convention and for serving in various governance capacities. At its September 1981 meeting, the Council approved in principle the expansion of the Association through the establishment of Organized Sections. The sections would provide political scientists with similar research or teaching interests not captured by traditional categories or forums for discussing issues of common concern. Organized Sections were designed as a "bottomup" means of defining fields of study and broadening the study of politics. Organized Sections were also meant to bring existing outside organizations into the fold by giving them a voice within the field's premiere professional association. Most importantly, the sections would share responsibility for creating panels for the Association's Annual Meeting and provide candidates for APSA Council. Political scientists focusing upon political psychology, economics, the life sciences, and specific policy areas already met at their own conventions or gatherings. The initiation of Organized Sections would create a bigger tent where these individuals could bring insights and concerns that had previously received only marginal consideration within traditional subfields.

Guidelines for establishing Organized Sections were developed by Thomas Mann and approved by the Council at its meeting in 1982. Guidelines included the recognition of sections by the Council upon petition by 100 members, the adoption of a section fee of $\$ 3$ per member, assistance from the Association in helping sections solicit members, the requirement that sections adopt pro- cedures and bylaws commensurate with APSA standards, and the inclusion of panels sponsored by Organized Sections in the official program ("APSA Council Minutes" 1982, 750). The role of the Organized Sections evolved over the next few years, with section leaders playing a larger role in the organization of the Annual Meeting.

Organized Sections first became formal participants in the Annual Meeting in 1983. The number of sections grew steadily from their inception until 1994. The growth in Organized Sections coincided with increases in Association membership. While it is not possible to show a causal relationship between the number of sections and growth in APSA membership because data does not exist for a number of relevant factors, ${ }^{2}$ it is clear that total membership climbed during the period that Organized Sections were expanding (see Table 2).

The expansion was similar for regular members and student members, with regular members registering a net gain of 1543 , and students a net gain of 1610, over the period. By 1994, APSA had made up for membership losses suffered in the 1974-84 period. The increase in membership does not seem to be related to an increase in the pool of political scientists. Five-year averages for Ph.D. awards in "political science and government" show a decline from 591.75 per year in the last half of the 1970 s to 409.2 per year in the late 1980s (National Research Council 1997).

The interests of the sections reflect diverse topics and methodologies. Most continue to focus upon traditional institutional concerns (e.g., Legislative Studies, Presidency Research) and standard subfield categories (e.g., Foundations of Political Theory, Comparative Politics). A large number reflect linkages with other disciplines (e.g., Political Economy, Politics and History, Politics and Life Sciences). Some emphasize applications from the discipline to society, the workplace, and the classroom (e.g., Science, Technology and Environmental Policy; Applied Political Science; Computers and Multimedia); while others 
Table 2

\section{APSA Membership and Growth in Organized Sections}

\begin{tabular}{|c|c|c|c|c|}
\hline Year & Regular & Student & $\begin{array}{c}\text { Total } \\
\text { Membership* }\end{array}$ & Sections \\
\hline 1984 & 5,891 & 2,511 & 9,042 & 6 \\
\hline 1985 & 5,879 & 2,595 & 9,273 & 8 \\
\hline 1986 & 6,009 & 2,589 & 9,465 & 9 \\
\hline 1987 & 5,913 & 2,775 & 9,610 & 17 \\
\hline 1988 & 6,171 & 2,728 & 9,837 & 17 \\
\hline 1989 & 6,445 & 3,054 & 10,595 & 20 \\
\hline 1990 & 6,708 & 3,436 & 11,233 & 23 \\
\hline 1991 & 6,967 & 3,656 & 11,767 & 25 \\
\hline 1992 & 7,046 & 3,740 & 11,963 & 28 \\
\hline 1993 & 7,061 & 3,979 & 12,255 & 30 \\
\hline 1994 & 7,505 & 4,121 & 12,933 & 32 \\
\hline
\end{tabular}

continue to reflect the influence of the behavioral revolution (e.g., Political Methodology; Elections, Public Opinion and Voting Behavior). A few others are reform oriented (e.g., New Political Science, Transformational Politics). Membership figures for Organized Sections show a wide range, from around one hundred to more than a thousand, though figures vary significantly from year to year (see Table 3). Sections organized around traditional and institutional topics have predictably attracted the most members. Among sections exploring linkages with other disciplines, 1994 membership figures ranged from a high of 737 (Political Economy) to a low of 106 (Politics and Life Sciences). Those sections focusing on applied political science (Applied Political Science; Science, Technology and Environmental Politics; Computers and Multimedia; Internships and Experiential Education) had somewhat lower overall memberships of between 109 and 255. Reform-oriented groups (New Political Science, Transformational Politics) also appeared to attract fewer members.

No doubt, many factors contributed to the increase in Association membership that coincided with increases in the number of Organized Sections, just as many factors certainly contributed to APSA's membership decline in previous years.
Yet, by 1991, APSA itself was touting the role sections played in revitalizing the Association. According to a staff report issued by Michael Brintnall (1991, 563), the Organized Sections "transformed APSAbroadening opportunities for participation and leadership without evidently weakening the spirit of common enterprise." Brintnall further claimed that the sections added to the diversity within a discipline that seeks "balance among varied interests and common goals." In the report, Brintnall noted that $45 \%$ of APSA members belonged to at least one Organized Section, and half of these section members belonged to more than one. He also reported that sections tended to attract slightly more regular faculty than students and those in government; those earning their degrees in the 1970s were more likely to be section members than retirees or those earning their degrees in earlier decades; and academics at the rank of associate professor were most likely to join sections $(1991,560)$. The leadership of the sections also brought greater gender diversity to APSA. As reported by Brintnall, while only $23 \%$ of all APSA members were female, $30 \%$ of Organized Section members were women-the same figure for overall female leadership in APSA.

\section{Coping With Success}

Despite the apparent success of Organized Sections in contributing to the revitalization of the Association, signs of stress soon became evident. Council members worried that continued specialization might fragment the Association. Some members expressed concern that there were "too many panels to attend [at the Annual Meeting], and too many panel sessions with small or no audiences" (Robert Hauck, personal communication, April 1998). Also of concern was finding space for the ever-increasing number of panels at the Annual Meeting.

In 1987, APSA Council affirmed a policy that the Annual Meeting be contained within a single hotel, to avoid the costs associated with the use of convention centers, and established an Ad Hoc Committee on the Structure of the Annual Meeting, to consider ways of allocating panels in a manner that would permit their housing within existing hotel facilities. The Ad Hoc Committee's first recommendation was to arrive at a fixed number of panels and to allocate $50 \%$ of them to the Program Committee to fill, $30 \%$ to the Organized Sections to fill, and $20 \%$ to Related Groups (those that were not part of the official program but which were given courtesy listing in the printed program) to fill. Future requests for panel allocations would be granted based upon the level of panel attendance, with the executive director of the Association playing a major role for the first time in monitoring attendance and allocating future panels (Brintnall 1991, 561). ${ }^{3}$

This approach was modified in 1989 , when the program chair used the subjects represented by the Organized Sections as a template for setting the official program. The hope was to avoid duplication of topics and, thus, reduce the number of panels. Organizers found, however, after the 1988 meetings that "Organized Sections did not encompass all fields and interests of the discipline" (Brintnall 1991, 562). Consequently, additional panels were added by the Program Com- 


\section{Table 3}

\section{Organized Sections in 1994}

\begin{tabular}{lc}
\hline \multicolumn{1}{c}{ Section } & Members in 1994 \\
\hline Federalism and Intergovernmental Relations & 342 \\
Law and Courts & 712 \\
Legislative Studies & 621 \\
Public Policy & 780 \\
Political Organizations and Parties & 511 \\
Public Administration & 657 \\
Conflict Processes & 275 \\
Representation and Electoral Systems & 348 \\
Presidency Research & 347 \\
Political Methodology & 517 \\
Religion and Politics & 347 \\
Politics and Life Sciences & 106 \\
Urban Politics & 431 \\
Applied Political Science & 109 \\
Science, Technology and Environmental Policy & 255 \\
Women and Politics & 536 \\
Foundations of Political Theory & 512 \\
Computers and Multimedia & 242 \\
International Security and Arms Control & 480 \\
Comparative Politics & 1014 \\
Politics and Society in Western Europe & 484 \\
State Politics and Policy & 443 \\
Political Communication & 352 \\
Politics and History & 516 \\
Political Economy & 737 \\
Transformational Politics & 146 \\
New Political Science & 244 \\
Political Psychology & 327 \\
Internships and Experimental Education & 165 \\
Politics and Literature & 184 \\
Public Opinion and Foreign Policy & 155 \\
Elections, Public Opinion and Voting Behavior & 309 \\
\hline Sorce R & \\
\hline & \\
\hline
\end{tabular}

Source: Rudder (1994a, 582). concerns about racial and gender diversity within the sections, despite the fact that APSA's own data demonstrated that the sections were at least as diverse as APSA leadership and, in some cases, more diverse than overall APSA membership. Lowi proposed that leaders of the Organized Sections be invited to assume an official role on the Program Committee. To insure diversity, Organized Sections were to nominate three candidates for the program committee, one of whom would be selected by the program chair of the Annual Meeting. This would give the chair "some flexibility to plan the overall meeting coherently and assure diversity in representation on the program committee." The plan would also, according to proponents, reduce the number of panel organizers by about a third and eliminate the duplication that came from having two sets of organizers. While some voiced concern at this time about proliferation of sections, APSA was still boasting that Organized Sections appeared "to provide new depth to our Association without causing the fragmentation that some feared" (Rudder 1991, 558).

In what had become a pattern, the Lowi "Rule of 3" was dropped within two years of adoption. The rule was attacked by some section leaders who argued that the sections were required to submit to increased bureaucratization without compensatory increases in services. In fact, some sections could claim that de-

spite meeting the reporting, membership, financial, and diversity requirements imposed by the Council, they were allotted fewer panels at the Annual Meeting than Related Groups that had to submit to very few APSA guidelines. ${ }^{4}$ Most importantly to the Council, however, the rule had not diminished requests for panel allocations or ameliorated concerns about hotel meeting space. 
Table 4

Section Requirements In Related Professional Associations*

\begin{tabular}{|c|c|c|c|c|c|}
\hline & $\begin{array}{l}\text { American } \\
\text { Political } \\
\text { Science } \\
\text { Association }\end{array}$ & $\begin{array}{l}\text { American } \\
\text { Sociological } \\
\text { Association }\end{array}$ & $\begin{array}{c}\text { American } \\
\text { Psychological } \\
\text { Association }\end{array}$ & $\begin{array}{c}\text { American } \\
\text { Anthropological } \\
\text { Association }\end{array}$ & $\begin{array}{c}\text { American } \\
\text { Association for } \\
\text { the Advancement } \\
\text { of Science }\end{array}$ \\
\hline Membership & $\begin{array}{l}12,933 \\
(1994)\end{array}$ & 13,000 & 126,083 & 10,000 & 143,000 \\
\hline Sections & 31 & 37 & 51 & 32 & $24^{\star \star}$ \\
\hline Minimum Membership (\%) & $\begin{array}{l}250 \\
(2 \%)\end{array}$ & $\begin{array}{l}200 \\
(2 \%)\end{array}$ & $.25 \%$ of membership & $\begin{array}{l}250 \\
(3 \%)\end{array}$ & \\
\hline
\end{tabular}

*Information from reports issued by each association.

${ }^{*}$ AAAS also has four regional divisions, each with their own meetings and officers. AAAS has 285 Affiliated Groups. These consist of 238 other societies, 44 state and regional academies of science, and three city academies. AAAS's combined number of affiliated members is more than 10 million.

Two task forces were created by Association President James Q. Wilson in 1992 to recommend additional changes.

At the April 1993 APSA Council meeting, a number of recommendations from task forces and ad hoc committees were merged into policies that resulted in the most important restructuring of Organized Sections since their inception in 1983. With the "Rule of 3" dropped, the Association was to assure diversity on the Program Committee by seeking the advice and consent of the program chair regarding appointments from the Organized Sections to the Committee. New rules were instituted prohibiting the same individuals from holding an Organized Section's program responsibilities for consectutive years. Organized Sections were urged to promote turnover of leadership and greater diversity within their ranks. The most important changes, however, related to the minimum size of the sections.

The Association Council in 1993 voted to increase the number of petitioners needed to organize a new section from 100 to 200 and to enforce a membership minimum of 250 dues payers for all sections. Organized Sections falling below the threshold would be given a year to increase their membership and those that could not deliver the required numbers would be encouraged to merge with other sections. The Council adopted a number of other policies that made it more difficult for sections to raise funds by selling ad space in section newsletters. Such sales would come, the Council feared, at the expense of lost revenue in official APSA publications. The Council did agree, however, to share revenues from the sale of section mailing labels and to permit section publications to use the APSA name in conjunction with the section name. As a rationale for these changes, the Council cited the need for sections officially participating in the Annual Meeting to "represent large scholarly communities with potential for breadth and diversity" (Rudder 1993, 583).

In increasing the numbers required to attain Organized Section status, APSA was not straying too far from common practice in related social science associations. The number of 250 members represented roughly $2 \%$ of overall membership, about the same number required for section status in other disciplinary groups (see Table 4). Nevertheless, the rule is not universal. The very large American Psychological Association requires only $.25 \%$ of members to form a section and has experienced similar growth in section numbers-apparently without serious complaint or difficulty (American Psychological Association 1997).

It did not take long for the new rule to have its intended effect of reducing the number of Organized Sections. Eight Organized Sections were initially placed in jeopardy by the "Rule of 250." Individually, these sections' memberships ranged from a low of 106 to a high of 244 . These groups were given an additional year to attain the required numbers. While some sections requested still more time to make plans for transition, such requests were denied. One section head, Christa Slayton, representing the Transformational Politics Section argued to the Council that its decision to implement this policy by the 1996 convention was "precipitous and undercut the ability [of section leaders] to attract new members" ("Draft Minutes" 1994b, 817). She argued for greater consultation with smaller sections, suggesting that APSA's fears of fragmentation were misplaced and that Organized Sections were responsible for the greater diversity and vigor that the Association had recently experienced (Slayton 1994). Some section leaders complained that the policy would increase inter-section competition for members and that political scientists paying dues in multiple sections would find it advantageous to drop out of those sections with low numbers. Formal and informal complaints by section leaders were dismissed by the Council and its members affirmed the 250 minimum requirement at their August 1994 meeting. Only one vote was recorded in opposition ("Draft Minutes" 1994b, 817).

By 1996, when the Annual Meeting program was first to reflect changes in policy, two of the Orga- 
Table 5

Status of Organized Sections in Jeopardy by Rule of 250

1994 Bubble Status

Computers

Transformational Politics

New Political Science

Internships

Literature

Foreign Policy

Politics and Life Sciences

Applied Political Science

*Source: Rudder (1994a, 582).

**Source: Rudder (1996a, 552) and personal communication with leaders.

${ }^{* * *}$ Members of this Section subsequently merged with the Organized Section on Public Policy.

nized Sections that were placed in jeopardy by the new ruling were decertified, three had managed to pull their numbers above the required margin, and the remainder had merged with other sections (see Table 5).

Within ten years of their creation, Organized Sections, which were hailed as responsible for reinvigorating the Association and returning its membership to levels not enjoyed since the 1970 s, had been subjected to at least five major policy revisions, the last of which began to move the Association in the direction of contraction and consolidation.

\section{A Tale of Two Sections}

Sections falling below the numerical threshold implemented in 1994 fell into one of three categories: those that survived, those that merged, and those that were decertified. Letters were sent in the fall of 1996 to representatives from all eight sections placed in jeopardy by the 1994 rule requesting information about steps taken to maintain section status, the results of such efforts, plans for the future, and reaction to the "Rule of 250." Responses from four sections were received. Two of these were from "merged" sections, one was from a section that managed later to attain the threshold, and one was from a decertified section.

One of the responses from a merged section indicated that it had undergone two name changes in two years-from Foreign Policy to Public Opinion and Foreign Policy to Domestic Sources of Foreign Policy. The section remains only minimally viable in terms of membership count, but the changes in its title indicate some problems in finding the right academic niche in order to sustain section status. A second merged section response came from a section that expanded in a predictable direction, changing its name from Computers to Computers and Multimedia. By 1996, this section was again in danger of being decertified because its membership had fallen to 236. Neither of these respondents replied to questions concerning ongoing operations and appraisal of the "Rule of 250 ." This lack of discussion may reflect leadership changes. Current leaders assumed their roles after the controversy over membership minimums had diminished. Some were not even aware of the problems that had plagued their sections just two years earlier.

Two additional responses were notable because of the way the sections in question have dealt with the membership rule, because of the insight these sections' responses can yield about the impact of the rule on the Organized Sections themselves, and because of the questions the responses raise about future directions within the discipline.

The Transformational Politics Section was one of the most vocal opponents of the membership minimum rule from its inception. Christa Slayton, section organizer during 1992-94, wrote several letters to the Committee on Organized Sections complaining that their action was precipitous, unfair to fledgling groups, and destructive of the greater diversity small groups brought to APSA. The membership rule placed the groups, Slayton complained, in the position of having to divert attention away from research and teaching efforts and towards recruitment. Her requests for reconsideration and delay of implementing the rule were denied. Facing potential extinction, the section began taking measures to increase its membership from 146 in 1994 to the requisite level of 250 .

As reported by Betty Zisk, the subsequent chair of the Transformational Politics Section (personal communication, January 1996), members of the section devoted "tremendous effort at the meetings themselves to publicizing our panels and our section and to recruiting new members." Other panels were asked to exchange membership lists. Still falling short in the fall of 1994 , the section offered free memberships to graduate students paid for by contributions from existing members. In addition, members enlisted colleagues in universities at which they worked-often with memberships paid by the existing member. By November of the same year, the section was able through these extraordinary means to boost membership to 260 .

By late 1995, however, the Section had lost members and fallen below the 250 level once again. Seeking a more lasting solution, members attempted to ally with other groups by offering joint memberships in a "kind of confederation." This approach yielded minimal results. The section next required section membership for presenters at the panels it sponsored-a practice common in other sections but untried previously by Transformational Politics on the philosophic grounds that it wanted 
Table 6

APSA Membership and Organized Sections Meeting Rule of 250

\begin{tabular}{ccccc}
\hline Year & Regular & Student & $\begin{array}{c}\text { Total } \\
\text { Membership }\end{array}$ & $\begin{array}{c}\text { Sections } \\
\text { Meeting } \\
\text { Threshold }\end{array}$ \\
\hline 1995 & 7,654 & 4,750 & 13,737 & 31 \\
1996 & 7,349 & 4,618 & 13,264 & 30 \\
1997 & 7,808 & 4,611 & 13,940 & $30^{* *}$ \\
\hline
\end{tabular}

* Includes Retired, Life, Family, and Associate Memberships. Thus, total membership is more than the sum of Regular and Student Memberships. Source: Rudder $(1997,596$.

${ }^{\star *}$ Because of the lag time between falling below the required number of members and decertification, 33 sections formally maintain Organized Section status, but three of these remain endangered and face decertification by 1999 unless they can pull to above the 250 threshold for at least one quarter of 1998 (Rudder 1997, 595).

to remain as "open as possible." Still, in order to meet the required numbers, some members "bought" memberships for those not willing or able to subscribe themselves. One individual paid for 31 new memberships. Finally, the group expanded its title to "Ecological and Transformational Politics" in hopes of attracting a larger constituency. In so doing, it risked encroaching on the domain of another existing sectionScience, Technology and Environmental Policy. As of the 1997 reporting period, the newly christened section had once again slipped below the required membership threshold for maintaining its Organized Section status.

Zisk reported that section members continue to be angry about the APSA Council action. While recognizing the need to balance stability with diversity, Zisk concluded: "Stability usually wins, and so too with APSA." The birth of the section, she claims, brought new members to APSA, individuals previously disaffected by the Association's lack of relevance to their personal research interests. A long time-member of APSA, Zisk recalled earlier attempts to open up the discipline to new ideas: "If the discipline had been as rigid (and as dominated by a single paradigm) in 1955-60, as it is now, I doubt very much if either the 'behavioral revolution' or the focus on comparative political development and political culture would have gotten off the ground." According to Zisk, APSA's downsizing reflects the changing mood of the nation in general and will result in less intellectual diversity within the Association.

One of the groups now decertified as an Organized Section is Politics and Life Sciences. Invested as an Organized Section in 1984, the membership of this group fluctuated widely from about 200 in the mideighties to just over 100 in 1994 , when it fell short of meeting the new 250-member minimum. The group attracted political scientists with wide-ranging interdisciplinary interests. Annual Meeting panel topics regularly included issues as diverse as health care policy, bioethics, and the potential applicability of new findings in primatology, neurophysiology, and genetics to the study of politics. As the section grew, it dedicated more resources to involving outside specialists in a wide variety of life science fields. It was not unusual for section-sponsored panels at the Annual Meeting to showcase guests from the natural sciences. Growth outside of political science led to the founding of a semiannual journal, Politics and the Life Sciences, attracting an international and interdisciplinary audience. Section officers believed the cultivation of these interdisciplinary ties was a boon to political science. Yet, growth of the organization was not reflected in new memberships in APSA. In fact, many of those speaking at the section's panels had to secure nonmember waivers in order to register for the Annual Meeting. To this day, political scientists make up only about $30 \%$ of the group's membership, according to its executive director, Gary Johnson. Remaining members come from more than thirty disciplines in twenty different countries (Johnson, personal communication, February 1997).

When notified that the section was in danger of being decertified, its leaders decided against taking extraordinary actions to increase memberships among Association colleagues. Instead, they chose to (1) revert to Related Group status; (2) hold their own research conferences; and (3) hold their own national conference separately from, but in conjunction with, APSA's Annual Meetings. Section leaders noted that, since there was no necessary connection between the number of panels allocated at the national convention and Organized Section status and since the Association placed virtually no bureaucratic restrictions on the operations of Related Groups in contrast to the growing array of regulations applied to Organized Sections, Politics and Life Sciences could opt for Related Group status and, as the Association for Politics and the Life Sciences (APLS), request the maximum number of panels for an organization of its size in this category. Beginning in 1995, APLS began holding occasional summer seminars, some at Alfred University, at which invitees presented results of new research in areas of interest to the group's members. This activity allowed nonpolitical scientists to participate without paying a fee and permitted a wider array of interested scholars to attend. In addition, the group initiated a plan to hold national conferences in the same location and at the same time as APSA held its Annual Meeting. This plan, first implemented in 1998 in conjunction with APSA's Annual Meeting in Boston, allowed APLS to organize its own panels and sessions as it pleased while, at the same time, drawing upon the close proximity of visiting 
political scientists already attending the APSA meeting. It is too early to assess the success of this last strategy, but, because this inaugural meeting drew over 220 paid registrants, this development warrants close examination by both sponsoring associations.

\section{Recent Developments}

Figures for 1995-97 show volatility among Organized Sections. In 1995, the number of Organized Sections decreased for the first time in eleven years. The active sections included only one new entry, Race, Ethnicity and Politics, which was given provisional status and one year to attain the required membership threshold, which it did meet in 1997. But, because each section must meet the 250-membership requirement each year, some of the sections that had survived the institutionalization of the "Rule of 250" in 1994 were in trouble again by the end of 1996 .

Computers and Multimedia, Transformational Politics, and New Political Science all fell below the required threshold in the latest reporting period (Rudder 1997, 595). Thirty sections remain clearly viable with memberships ranging from 1,389 (Comparative Politics) to a bare minimum of 258 (Politics and Literature). While APSA membership suffered a small decline during the period when the number of Organized Sections decreased (Table 6), it has since rebounded. Association members seem to be re-sorting themselves among remaining Organized Sections. But with three of the remaining Organized Sections currently failing to meet the membership requirement and at least two more precipitously close to that number, organizational stability may not yet have been achieved.

\section{Future Directions}

As organizations grow, they are faced with justifiable concerns about managing that growth and maintaining a distinctive identity. The problem for APSA, however, is that there is little distinctive historical identity to fall back upon as it attempts to deal with the phenomenal growth it has experienced since the inception of Organized Sections. It is clear that creating Organized Sections had the desired effect of revitalizing the Association. Yet, the Association's principal desires to maintain disciplinary continuity and to keep the size of its Annual Meeting manageable, were bound to collide with the growth it set in motion when it created Organized Sections. Its recent actions to constrain the proliferation of sections and to exert more control over their functioning were bound to decrease the overall number of sections and to meet with reactions ranging from apathy to hostility to the inauguration of separate national meetings.

Preliminary indications are that the recent contraction of Organized Sections has not adversely affected Association membership and that members have re-sorted themselves among remaining sections. However, more stringent organizing rules may have a long-term impact on intellectual diversity within the profession, inhibiting the opportunity for small groups of like-minded researchers to serve as incubators for novel ideas and approaches while maintaining formal linkages with the Association. As Zisk (1997) noted, it takes more than ten years for some subfields to attract a sizable following. Employing content analysis of articles appearing in the American Political Science Review, Zisk showed that it took approximately thirty years for economic and formal modeling approaches to gain a respectable share of space in the discipline's premiere journal.

One possible response to the need for both continuity and inclusion might be for APSA to move toward a confederated organization, much like AAAS, breaking into smaller regional units that exploit the diversity of interests fostered by regional centers of expertise. For example, a Midwestern Association might specialize in bringing together specialists in the study of institutions, leaving other regional divisions to specialize in other subfields and interests. State units might operate either in conjunction with alreadyexisting regional associations, like the Midwest Political Science Association, or independently. ${ }^{5}$

Underlying debates over the rules for Organized Sections and economic discussions about expanding the Annual Meeting to include more hotels, is the increasingly expressed concern that the field is becoming too diverse. There has been talk of the need to "represent large scholarly communities" (Rudder 1993, 583). A past president has warned of the proliferation of "separate tables," making communication across subfields increasingly difficult (Almond 1988). These seem to be legitimate concerns from an organizational perspective. But, from an historical vantage, American political science simply appears to remain true to the diversity that has marked its development. The period of Organized Section expansion represented an attempt by APSA to nurture this native diversity within the established confines of a national organization. If history is a guide, APSA's current effort to constrain Organized Section growth is not likely to curb the problem of "separate tables." It is simply likely to drive some tables elsewhere. What is less certain is whether APSA will continue to plot its own growth by nurturing the diversity that is endemic to the field or if the Association will be content to represent only some subset of interests that characterize the study of politics. 


\section{Notes}

1. There are, no doubt, multiple reasons for the decline in APSA membership during the period from 1974 to 1982 , including a depressed labor market for academics and a stagnant U.S. economy. Yet, the precise relationship between these factors and organizational membership remains opaque. The fact that membership in APSA grew from 1983 to 1994, when job prospects did not substantially improve and when the number of Ph.D. awards in political science actually shrank, shows that the relationship between employment and economic factors, on the one hand, and organizational membership, on the other, is not simple and straightforward.

2. It would be useful to track the number of new members who joined Organized Sections upon joining the Association. But, according to Sheilah Mann, APSA did not keep records of this sort in-house until well into the current decade. The collection of membership information and numbers prior to this period was contracted out to a separate entity (Sheilah Mann, personal communication, January 1997).

3. The Council devised a complex formula in 1990 keyed to growth in membership and panel attendance that permits panels to be held outside a single hotel (Robert Hauck, personal communication, April 1998).

4. As I have been reminded by the editor of PS (personal communication, April 1998), there are some Related Groups that, for their own reasons, do not wish to become Organized Sections, yet which, because of high panel attendance, warrant a higher number of panel allocations than some Organized Sections.

5 . There is some indication that a move in this direction may be under consideration. "At its most recent meeting, the Midwest Political Science Association's leadership held a retreat to consider changing the name of the regional association to something that corresponds to their national membership" (Robert Hauck, personal communication, April 1998).

\section{References}

Almond, Gabriel A. 1988. "Separate Tables: Schools and Sects in Political Science." PS: Political Science and Politics 21(Fall): 828-42.

American Psychological Association. 1997. Handbook for Division Officers. Washington, DC: APA

“APSA Council Minutes." 1982. PS 15(Fall): $750-51$.

Berger, Peter L., and Thomas Luckman. 1966. The Social Construction of Reality: $A$ Treatise in the Sociology of Knowledge Garden City, NJ: Doubleday.

Brintnall, Michael. 1991. "Organizational Sections: A Status Report." PS: Political Science and Politics 22(September): 55963.

Carley, Kathleen. 1991. "A Theory of Group Stability." American Sociological Review 56(3): 331-54

"Draft Minutes: APSA Council Meeting." 1994b. PS: Political Science and Politics 27(December): 814-18.

"Draft Minutes: APSA Council Meeting." 1995. PS: Political Science and Politics 28(December): 856-60.

"Draft Minutes: APSA Council Meeting. 1996b. PS: Political Science and Politics 29(September): 618-23.

Easton, David. 1993. "Political Science in the United States: Past and Present." In Disci pline and History: Political Science in the United States, ed. James Farr and Raymond Seidelman. Ann Arbor: University of Michigan Press.

Farr, James. 1993. "Political Science and the State." In Discipline and History: Political Science in the United States, ed. James Farr and Raymond Seidelman. Ann Arbor: University of Michigan Press.
—, and Raymond Seidelman, eds. 1993. Discipline and History: Political Science in the United States. Ann Arbor: University of Michigan Press.

Kuhn, Thomas. 1962. The Structure of Scientific Revolutions. Chicago: University of Chicago Press.

Lowi, Theodore. 1993. "The State in Political Science: How We Become What We Study." In Discipline and History: Political Science in the United States, ed. James Farr and Raymond Seidelman. Ann Arbor: University of Michigan Press.

Merton, Robert K. 1938. "Science, Technology and Society in Seventeenth Century England." In Osiris: Studies on the History and Philosophy of Science, ed. Robert K. Merton. Bruges, Belgium: St. Catherine Press.

—. 1973. "Paradigm for a Sociology of Knowledge," In The Sociology of Science, ed. N. Storer. Chicago: University of Chicago Press.

National Research Council. 1997. Survey of Earned Doctorates. Washington, DC: National Academy Press.

Ross, Dorothy. 1993. "The Development of the Social Sciences." In Discipline and History: Political Science in the United States, ed. James Farr and Raymond Seidelman. Ann Arbor: University of Michigan Press.

Rudder, Catherine. 1990. "Report of the Executive Director." PS: Political Science and Politics 23(September): 478-82.

. 1991. "Report of the Executive Director." PS: Political Science and Politics 24(September): 556-59.

—. 1993. "Report of the Executive Direc- tor." PS: Political Science and Politic 26(September): 582-87.

—. 1994a. "Report of the Executive Director." PS: Political Science and Politics 27 (September): 580-83.

—. 1996a. "Report of the Executive Director." PS: Political Science and Politics 29(September): 549-54.

— 1997. "Report of the Executive Director." PS: Political Science and Politics 30(September): 592-99.

—. 1998. "Executive Director's Report." PS Political Science and Politics 31(September): $659-72$.

Seidelman, Raymond, 1993. "Political Scientists, Disenchanted Realists and Disappearing Democrats." In Discipline and History: Political Science in the United States, ed. James Farr and Raymond Seidelman. Ann Arbor: University of Michigan Press.

Slayton, Christa D. 1994. "Response to Organized Section Committee Decisions." Submitted to APSA Committee on Organized Sections. Made available by author.

Somit, Albert, and Tanenhaus, Joseph. 1967. The Development of American Political Science from Burgess to Behavioralism. Boston: Allyn \& Bacon.

Van Dyke, Vernon. 1960. Political Science: $A$ Philosophic Investigation. Stanford: Stanford University Press.

Zisk, Betty. 1997. "The Discipline At Century's End: Ecological Critique." Paper presented at the Annual Meeting of the American Political Science Association, Washington, DC. 